\title{
FIXED ASSET MANAGEMENT OF BUILDINGS AND STRUCTURES TO INCREASE ROTE NDAO REGENCY LOCAL REVENUE THROUGH A NEW PUBLIC MANAGEMENT PERSPECTIVE: A STUDY AT THE DEPARTMENT OF CULTURE AND TOURISM OF ROTE NDAO REGENCY, INDONESIA
}

\author{
Manafe Jerminsyah S.P., Djaha Ajis S. Adang, Rozari Petrus E. De \\ Master's Program in Administrative Sciences, Postgraduate Program, \\ University of Nusa Cendana, Kupang, Nusa Tenggara Timur, Indonesia \\ *E-mail: manafeermin@gmail.com
}

\begin{abstract}
This research aimed to determine and analyze fixed asset management of buildings and structures to increase Local Revenue (Pendapatan Asli Daerah - PAD) through a new public management perspective in the Department of Culture and Tourism of Rote Ndao Regency, Indonesia. This research used the qualitative method and case study approach. The research focused on a New Public Management (NPM) perspective in the Department of Culture and Tourism of Rote Ndao Regency, Indonesia. We described this focus into several sub-focus: (a) asset planning; (b) asset organization; (c) asset implementation; (d) asset supervision; and (e) asset accountability. This research was conducted in the Department of Culture and Tourism of Rote Ndao Regency, Nusa Tenggara Timur Province, Indonesia. We used the purposive sampling technique to determine informants. The data source was primary data and secondary data. The data collection used interviews, documentation, and observation. Data analysis used Creswell (2016) validation technique. The research result showed the Department of Culture and Tourism of Rote Ndao Regency experienced obstacles during asset planning, asset organization, asset implementation, and asset supervision.
\end{abstract}

\section{KEY WORDS}

Asset management, local revenue, new public management.

Asset management is a part of financial management. It is generally related to regional development administration. Asset management refers to asset value, asset utilization, asset value record in the balance sheet, and development priority list. Hidayat (2011:7) defines asset management as an efficient and fair method to allocate resources between goals and objectives legally and competitively. Suharyanto (2005:11) describes the scope of asset management into several activities such as planning, procurement, inventory, storage, distribution, treatment, and evacuation.

Rote Ndao Regency is an autonomous region in Indonesia. Therefore, Rote Ndao Regency uses the asset management concept in regional development strategies to optimize regional sources of revenue integrally. Rote Ndao Regency is part of East Nusa Tenggara Province and the southernmost island in Indonesia. The Indonesian government established Rote Ndao Regency as an autonomous region in 2002 based on Law Number 9 of 2002 concerning the Establishment of the Rote Ndao Regency in East Nusa Tenggara Province. Rote Ndao Regency has been an autonomous region for 18 years and has undergone three changes of regional heads. The current government period (2019-2023) carries the vision of "the realization of the Rote Ndao community possessing dignity based on tourism development supported by agriculture and fisheries".

Three governance periods show non-optimal regional asset management. The regional asset management did not achieve maximum efficiency and effectiveness. It failed to increase PAD, as reflected through the revenue and expenditure budget (Anggaran Pendapatan and Belanja Daerah - APBD). Annual APBD showed a significant deficit compared to regional government spending. Based on Rote Ndao Regency PAD data, the 
regional revenue was IDR 778,814,668,579.30, and regional expenditure was IDR $878,457,620,489.26$. The data showed a regional financial deficit of IDR 99,642,951,099.96.

Therefore, it is necessary to efficiently and effectively collect PAD through good regional asset management. The asset is one of the components in the regional government financial report. Table 1 shows the total fixed asset of the Rote Ndao Regency Government:

Table 1 - Rote Ndao Regency Government Fixed Asset as of $31^{\text {st }}$ December 2019

\begin{tabular}{|c|c|c|c|c|}
\hline & Description & Total & Unit & Value (IDR) \\
\hline \multicolumn{5}{|c|}{ CENTRAL GOVERNMENT } \\
\hline 1 & TRANSPORTATION EQUIPMENT & 4 & Unit & $61,700,000.00$ \\
\hline \multicolumn{5}{|c|}{ ROTE NDAO REGENCY GOVERNMENT } \\
\hline 1 & LAND & 909 & Area & $54,517,621,896.00$ \\
\hline 2 & HEAVY EQUIPMENT & 205 & Unit & $15,669,778,712.00$ \\
\hline 3 & TRANSPORTATION EQUIPMENT & 1,221 & Unit & $68,701,826,124.05$ \\
\hline 4 & WORKSHOP TOOLS AND MEASURING TOOLS & 1,604 & Unit & $4,092,852,171.00$ \\
\hline 5 & AGRICULTURE TOOL & 1,105 & Unit & $4,985,537,300.00$ \\
\hline 6 & OFFICE AND HOUSEHOLD TOOL & 85,001 & Unit & $73,695,129,930.04$ \\
\hline 7 & STUDIO TOOL AND COMMUNICATION TOOL & 992 & Unit & $4,420,977,252.00$ \\
\hline 8 & MEDICAL TOOL & 14,958 & Unit & $53,721,219,421.40$ \\
\hline 9 & LABORATORIUM TOOL & 19,314 & Unit & $45,997,232,716.00$ \\
\hline 10 & WEAPONS/SAFETY EQUIPMENT & 392 & Unit & $188,143,303.00$ \\
\hline 11 & BUILDING & 2,079 & Unit & $506,486,742,180.75$ \\
\hline 12 & MONUMENT & 754 & Unit & $8,098,018,462.00$ \\
\hline 13 & ROAD AND BRIDGES & 589 & Unit & $733,365,284,945.61$ \\
\hline 14 & WATER FACILITY/IRRIGATION & 728 & Unit & $283,210,365,259.82$ \\
\hline 15 & INSTALLATION & 531 & Unit & $35,930,900,776.15$ \\
\hline 16 & NETWORK & 175 & Unit & $33,780,947,058.18$ \\
\hline 17 & BOOK AND LIBRARY & 102,050 & Piece & $31,515,438,943.00$ \\
\hline 18 & CULTURAL ITEM & 1,016 & Piece & $3,704,913,995.00$ \\
\hline 19 & ANIMAL, LIVESTOCK, AND PLANTS & 4 & Package & $42,000,000.00$ \\
\hline & CONSTRUCTION IN PROGRESS & 9 & Unit & $1,913,006,800.00$ \\
\hline & AL & 233,640 & & $1,964,099,637,246.00$ \\
\hline
\end{tabular}

Source: Asset Sector, Rote Ndao Regency Financial and Asset Agency (Badan Keuangan and Asset - BKA).

Table 1 shows the existing asset of the regional government. The asset provides economic benefit to Rote Ndao Regency and the community. Therefore, good asset management supports Rote Ndao's effort to realize good governance and measure of opportunity. Adequate PAD may improve Rote Ndao Regency governance. Out of existing fixed assets, buildings and structures are the most crucial asset. Buildings and structures determine the performance of a region. Rote Ndao Regency Government develops buildings and structures annually to increase community service and PAD.

Based on observation results, Rote Ndao Regency building and structure assets are used by 36 Regional Organizations (Organisasi Perangkat Daerah - OPD). However, only 9 OPDs have potential assets to increase PAD. However, the lack of appropriate asset management incurred the regional government large maintenance costs. The OPDs carry the Vision of Rote Ndao Regency (realizing a dignified Rote Ndao community-based tourism development supported by agriculture and fisheries). However, 2 OPDs did not have a PAD target in 2019, one of which is The Department of Culture and Tourism.

Based on the data above, 2 OPDs obtained minimum revenue. However, we focused on the Department of Culture and Tourism. In 2017 and 2018, the Department of Culture and Tourism had very low revenue. In 2019, the Department of Culture and Tourism did not set a PAD target. The Department of Culture and Tourism assets potentially increase PAD. However, the Department of Culture and Tourism did not utilize the assets optimally. Therefore, the assets remained unused and did not increase Rote Ndao Regency PAD.

Based on the background of the research, it is necessary to determine and analyze the appropriateness of asset management theory and asset management implementation in the Department of Culture and Tourism of Rote Ndao Regency. Therefore, we conducted a study on Fixed Asset Management of Buildings and Structures to Increase Rote Ndao Regency PAD through NPM Perspective (A Study of Department of Culture and Tourism of Rote Ndao 
Regency). This research aimed to determine and analyze fixed asset management of buildings and structures to increase PAD through the NPM perspective in the Department of Culture and Tourism of Rote Ndao Regency.

\section{LITERATURE REVIEW}

Ghillyer (2016:4) states that management is the process of determining the best way for an organization to use its resources to produce goods or services. According to Samson and Daft (2012:10), management is the achievement of organizational goals effectively and efficiently through planning, organizing, leading, and controlling organizational resources. According to Schermerhorn et al. (2011:19), management is the process of planning, organizing, leading, and controlling the use of resources to achieve performance objectives. According to Robbins and Coulter (2009:22), management involves coordinating and supervising the work activities to ensure efficient and effective activity completion. Merchant and Stede (2007:6) state that management is all that relates to the process of organizing resources and directing activities to achieve organizational goals.

Based on the definitions above, management is a science that directs different people to achieve the same goals in an organized manner and has a plan to process existing resources effectively and efficiently.

Hood (1991:4) introduced the concept of New Public Management. Based on a historical perspective, the modern approach to the public sector emerged from European countries in the 1980s and 1990s due to inadequate traditional public administration models. Denhart and Robert (2007:12) explain that NPM refers to a group of contemporary ideas and practices that essentially use a private-sector approach and business in the public sector. NPM has become normative, which signals a major shift in the role of public administrators. Bovaird and Loffer (2013:17) state that NPM is a movement that streamlines the public sector. NPM makes the public sector comparative and tries to make public administration more responsive to citizens' needs by offering economic measurement, efficiency and effectiveness (value for money), flexibility of choice, and transparency.

Implementation of the NPM concept is a form of modernization or reform of management and public administration, depoliticization of power, or decentralization of authority that promotes democracy. Some believe that the NPM paradigm is an international phenomenon as part of a global process. NPM quickly influenced public management practice in various countries and encouraged the establishment of a worldwide movement.

According to Halim (2007:23), regional finances are all rights and obligations possessing monetary value, units in the form of money or goods that can be used as regional assets as long as they are not owned/controlled by a higher state, region, or other parties in accordance with applicable laws and regulations. Government Regulation Number 58 of 2005 states that regional finance is all regional rights and obligations in administering regional government with monetary values, including all forms of wealth related to the rights and obligations of the region.

According to Sumarsono (2009:35), regional finances are all regional rights and obligations with monetary values and everything in the form of money or goods that can be used as regional property related to the implementation of rights and obligations. Sumarsono further explains that regional rights are an effort made by the regional government to increase the regional treasury. These regional rights include the right to collect regional taxes and regional levies. In addition, regional rights allow the government to make loans. Regional obligations refer to carrying out regional government affairs and paying bills to third parties. Therefore, regional finances are all rights and obligations with monetary values or regional assets. In this study, regional assets refer to Rote Ndao Regency assets regulated by applicable laws.

To understand asset management in Rote Ndao Regency, it is necessary to understand the meaning of regional assets based on expert theory and the applicable laws and regulations. According to the Indonesian Valuation Standards (Standar Penilaian Indonesia - SPI) in accounting terminology, assets are resources owned or controlled by a 
business entity or government. Assets provide future economic or social benefits and can be measured in units of money. Based on the management aspect, asset valuation is something legally owned. Asset valuation can increase the value and development of the resources.

According to Siregar (2004:198), assets are goods with economic, commercial, or exchange values owned by a business entity, agency, or individual. For regional governments, assets are a very important resource to support PAD. Therefore, regional governments must be able to manage assets appropriately and optimally.

Asset management has developed globally. However, the Indonesian regional governments have not implemented asset management optimally. Regional government asset management is divided into five stages: asset inventory, legal audit, asset valuation, optimization of utilization, and development of asset management information system. The stages are interconnected and integrated (Siregar, 2004:518).

- Asset inventory is an activity that consists of two aspects: physical and juridical/legal inventory. Physical aspects consist of shape, area, location, volume/amount, type, address, etc. The juridical aspects refer to control status, legal issues, ownership limit. Asset inventory processes are data collection, codification (labeling), grouping, and bookkeeping or administration. The processes adhere to the objectives of asset inventory;

- Legal audits. The scope of asset management is an inventory of asset control status, systems, and procedures for asset control or transfer, identifying and finding solutions to legal problems, and strategies to solve various legal problems related to asset control and transfer;

- Asset valuation assesses assets controlled by the regional government and is usually carried out by an independent valuation consultant. The valuation result determines total wealth and information for pricing assets to be sold;

- Asset optimization is an activity to optimize the physical, location, value, amount (volume), legal and economic potential of the asset;

- Supervision and control. The most effective means to improve supervision and control is developing Asset Management Information System (Sistem Informasi Manajemen Aset - SIMA). SIMA guarantees work transparency and improve supervision and control. SIMA accommodates the previous aspects and allows clear asset monitoring (scope and responsible individual).

\section{METHODS OF RESEARCH}

This research used the qualitative method and case study approach. The research focused on the NPM perspective in the Department of Culture and Tourism of Rote Ndao Regency, Nusa Tenggara Timur Province, Indonesia. We described this focus into several sub-focus: (a) asset planning, (b) asset organization, (c) asset implementation, (d) asset control, and (e) asset accountability. We conducted the study in the Department of Culture and Tourism of Rote Ndao Regency. The researcher used the purposive sampling technique to determine informants. The data source was primary data and secondary data. The data collection used interviews, documentation, and observation. Data analysis employed Creswell (2016) validation technique. The research results showed that fixed asset management of buildings and structures to increase PAD through the NPM perspective in the Department of Culture and Tourism of Rote Ndao Regency experienced obstacles during asset planning, asset organization, asset implementation, and asset supervision.

\section{RESULTS AND DISCUSSION}

Hood (1991:4) states that NPM requires professional public sector management starting from the planning stage. Findings confirmed the obstacles the Department of Culture and Tourism of Rote Ndao Regency encountered during the asset planning process. The Department did not establish a regulation to obtain benefits from building and structure assets. Therefore, the Rote Ndao Regency did not benefit from existing tourism destinations. 
Rote Ndao Regency did not set a PAD target nor obtain revenue from the tourism sector. Therefore, the phenomenon contrasted Osborne and Gaebler's (1996:88) NPM theory. Osborne and Gaebler state that NPM is an effort to transform the spirit and performance of entrepreneurs (entrepreneurship) into the government bureaucracy. To further realize the concept of NPM in the public bureaucracy, bureaucratic leaders need to increase productivity and find alternative ways of providing public services based on an economic perspective.

Based on the Ministry of Home Affairs Regulation Number 9 of 2016 concerning Guidelines for the Management of Regional Property, needs planning is an activity to formulate details of regional property needs to link past procurement of goods with ongoing conditions as a basis for future actions. The guidelines were reinforced by Law Number 23 of 2014 concerning Regional Governments in implementing real, dynamic, and responsible regional autonomy. Funding sources are necessary to carry out regional governance and development utilizing existing regional capabilities. Article 79 of Law No. 23 of 2014 states that regional revenue sources can be the original regional revenue, balancing funds, regional loans, and other legitimate revenue. PAD includes regional taxes, user fees, regional companies, the management of separated regional assets, and other legitimate regional revenue. PAD finance the implementation of regional autonomy. Therefore, increasing PAD will improve community service. However, the Rote Ndao Regency and the Department of Culture and Tourism did not set PAD or regional revenue targets through levies and utilization of tourist sites.

Rote Ndao Regent and the Department of Culture and Tourism need to synchronize in asset management to realize the vision of Rote Ndao Regency: The NPM's main goal is to increase the Rote Ndao Regency community welfare. However, the Department of Culture and Tourism has not implemented NPM optimally. The Department of Culture and Tourism did not utilize PAD for the benefit of the community. It failed to implement the NPM through public sector finance reform to create public-oriented finance and emphasize value for money.

Organizing is part of the management function, namely the allocation/formation of role structures to delegate the Department of Culture and Tourism Office of Rote Ndao Regency. Based on Duffuaa et al. (1999:17), the management function seeks to synchronize existing resources at the Department of Culture and Tourism of Rote Ndao Regency to achieve organizational goals. Resources refer to natural resources, human resources, capital resources. Asset organizations divide a complex job into simple work for individuals or groups. Organizing asset maintenance system refers to job design consisting of asset maintenance, equipment, human resources, the time standard to complete asset maintenance, and periodic project management or maintenance.

The Department of Culture and Tourism implemented bidding on fixed assets of buildings and structures based on the research result. The Department of Culture and Tourism aims to create competitiveness in the public sector, reduce cost, increase quality, and privatization. The tender method seeks competent bidders who can produce government services in the desired form and time at the lowest possible cost.

Bidding refers to an agreement between the government and a service company regarding projects/work with a clear scope. The bidder supplies the project to the community. However, the government has the overall responsibility and quality control. Hanafi and Nugroho (2009) affirm that the NPM incurs consequences to the government, such as demand for efficiency, cost-cutting, and tender competition.

Involving the private sector creates competitiveness and increases risk. However, open bidding as a control instrument is crucial to increase community orientation and reduce costs. Therefore, open bidding reduces the burden of Rote Ndao Regency APBD.

However, utilizing a third-party consultant to maintain building and structure assets creates negative consequences. Asset maintenance occurs when Rote Ndao Regency Government allocates the budget. Due to a lack of maintenance and budget, the third-party consultant has no sense of ownership over the building and structure asset.

The Department of Culture and Tourism identifies the non-beneficial and unused assets. It analyzes the existing problem. For example, ineffective asset reduces supporting 
activities for other assets. This was one example of the reason behind the failure of the Department of Culture and Tourism to maintain assets optimally.

Maintaining asset benefit and potential should be a high priority during decisionmaking. The length of the asset utilization period depends on the level of asset maintenance for certain objectives. Therefore, it is necessary to evaluate asset ownership and verify the asset outcome (Hariyono, 2007:135). The regional asset is a crucial resource to support PAD. Therefore, the Regional Government need to manage asset appropriately to improve regional asset contribution.

The research result showed that the Department of Culture neither set revenue targets nor supported the regional economy (PAD from tourism destination) for community welfare.

Supervision refers to leadership ensuring and guaranteeing the implementation of organizational tasks and objectives. Leadership ensures the organizational activities adhere to predetermined policy, instruction, plan, and regulation (Lembaga Administrasi Negara, 2011). According to Fayol (1985:102), controlling is supervising, proving, and ensuring the organizational activity undergoes management function. Controlling ensures organizational activities adhere to targets and standards.

Supervision, control, and guidance are necessary to ensure orderly administration, effectiveness, and efficiency of regional property (Barang Milik Daerah - BMD) management. BMD management does not merely refer to administrative management. Orderly, accountable, and transparent BMD management increase efficiency, effectiveness, and added value. Regulation of the Minister of Home Affairs Number 19 of 2016 concerning Technical Guidelines for the Management of Regional Property explains that control is an effort or activity to ensure and direct certain tasks to adhere to a predetermined plan. Supervision is an activity to determine and assess the real condition of activity implementation. Supervision ensures the activity implementation adheres to existing laws. The Department of Culture and Tourism supervised assets based on the Head of Department Decree. The Department of Culture and Tourism needs to submit a periodic report to the treasurer and the Regent. The asset supervision management adhered to Minister of Home Affairs Number 19 of 2016 concerning Guidelines for the Management of Regional Property Article 481.

The Department of Culture and Tourism implemented the NPM principle in asset supervision management. In a broader context, the state administration paradigm has more attention to responsiveness to the public than the old state administration paradigm that focuses on internal state administration and governance (Frederickson, 1984:122). Based on the research result, the Department of Culture and Tourism did not implement supervision functions according to targets and standards. In this case, the Department of Culture of Tourism could not utilize PAD to improve regional development and community welfare.

To create an asset management system in the form of buildings and structures of the Department of Culture and Tourism, it is necessary to establish a regional asset accountability system. Siagian (1995:98) describes the asset accountability through the following processes:

- Asset data collection time;

- Reporting/accountability, which consists of daily reports, weekly reports, monthly reports, quarterly reports, semiannual reports, and annual reports;

- Forms of accountability consist of financial reports, activity reports, performance reports.

Tjitrosidojo (1977:90) explains that a good management process requires detailed reports and accountability as input for related parties to formulate a beneficial decision.

The Department of Culture and Tourism, assisted by the officials of the Administration of Goods, manages the regional asset. The management accountability adheres to Minister of Home Affairs Regulation Number 19 of 2016 concerning Technical Guidelines for the Management of Regional Property which stated that explained that control is an effort or activity to ensure and direct certain tasks to adhere to a predetermined plan. Supervision is an activity to determine and assess the real condition of activity implementation. Supervision assesses whether the activity implementation follows the existing laws. 
It is necessary to control the management system and procedure to deter issues during operational implementation. Management procedures and systems refer to various regulations. Managers of assets/goods need to adhere to the regulation (Regional head, Head of OPDs, technical officials) to realize good governance. Based on the research result, the Department of Culture and Tourism has good asset accountability.

\section{CONCLUSION}

The fixed asset management of buildings and structures encountered various obstacles, which are described as follows:

- Asset planning of 2018 - 2020 uses APBD and State Budget (Anggaran Pengeluaran and Belanja Nasional - APBD) such as Special Allocation Funds (Dana Alokasi Khusus - DAK) and General Allocation Funds (Dana Alokasi Umum - DAU). However, the Department of Culture and Tourism did not allocate a budget annually. Instead, the Department of Culture and Tourism allocated a budget when asset maintenance was necessary. There is a lack of PAD revenue strategy due to a lack of regulation on levy collection;

- Non-optimal asset organization because the Department of Culture and Tourism allocated budget when asset maintenance was necessary;

- Asset implementation did not have a revenue target and realization due to lack of Regional Regulation;

- Based on the NPM perspective, the Department of Culture and Tourism ineffectively supervised and managed assets to increase PAD. Rote Ndao Regency failed to implement the Vision of Rote Ndao Regency. Therefore, Rote Ndao Regency did not optimize the budget and fixed assets of buildings and structures to improve community welfare.

\section{SUGGESTIONS}

The regional asset is a crucial resource for Rote Ndao Regency and supports PAD. Regional governments need to manage assets appropriately. Therefore, the regional asset may optimally contribute to PAD. Therefore, the regional governments must use the NPM perspective. The regional governments may generate profit instead of spending budget. For example, the government may loan assets to third parties to increase PAD. In addition, it is necessary to allocate a budget to maintain assets and increase human resources. The human resources may manage and supervise the asset and increase the regional asset utilization levy. The government needs to establish regional regulations policies to legitimize the management of regional assets in a professional, transparent, accountable, efficient, and effective manner for regional asset planning, organizing, implementing, monitoring, and accountability. Therefore, the Department of Culture and Tourism of Rote Ndao Regency may fully utilize fixed assets of building and structure to improve tourism PAD and realize the vision of Rote Ndao Regent.

Due to the limited resources in the fixed asset of buildings and structures, the Head of the Department of Culture and Tourism needs to understand that asset consumption is a significant cost to Rote Ndao Regency APBD. Therefore, the Department of Culture and Tourism needs an effective and efficient management system following the NPM perspective. The public sector organization pays attention to economic and efficient resource utilization. The Department of Culture and Tourism needs to maintain the costs of service provision to reduce demand for new assets by adopting non-asset solutions, maximizing the potential benefits of existing assets, reducing the overall cost of owning assets through the use of life cycle cost techniques, focusing on the results, reducing liability, and maintaining clear asset accountability. Asset management is a systematic and structured process covering all assets assuming that the asset supports service provisions-in this case, public sector organization services in the tourism service sector. 


\section{REFERENCES}

1. Creswell, John W. 2016. Penelitian Kualitatif \& Desain Riset. Yogyakarta: Pustaka Pelajar.

2. Hidayat Muchtar. 2011. Manajemen Aset (Privat and Publik). Yogyakarta: LaksBang.

3. Suharyanto. 2005. Manajamen Sumber Daya Manusia. Yogyakarta: Media Wacana.

4. Ghillyer, Andrew. 2016. Business Ethics: A Real World Approach. New York: McGrawHill Irwin.

5. Schermerhorn, J.R, Hunt, J.G., \&Osborn, R.N. 2011. Managing Organizational Behaviour. New York: John Willey \& Son.

6. Robbins, Stephen P and Mary Coulter. 2009. Management. United State America: Pearson.

7. Merchant, K.A. and Stede, W.A. 2007. Management Control Systems: Performance Measurement, Evaluation, and Incentives. 2nd Edition. London: Prentice Hall.

8. Hood C. 1991. A Public Management For All Seasons?. Public Administration: 69 (spring): 3-19.

9. Denhardt, Janet and Robert Denhardt. 2007. The New Public Service. Serving notvSteering. ME Sharpe LGSP: Legislative Strengthening Team.

10. Bovaird, T. Loffer, E. 2013 Public Management and Governance. New York: Routledge.Buhr.

11. Halim Abdul. 2007. Pengelolaan Keuangan Daerah. Edisi Ketiga. Yogyakarta: UPP STIM YKPN.

12. Sumarsono, Sonny. 2009. Ekonomi Sumber Daya Manusia Teori and Kebijakan Publik. Yogyakarta: Graha Ilmu.

13. Siregar, D.2004. Manajemen Aset. Strategi Penataan Konsep Pembangunan Berkelanjutan Secara Nasional dalam Konteks Kepala Daerah Sebagai CEO's pada Era Globalisasi and Otonomi Daerah. Jakarta: Gramedia Pustaka Utama.

14. Hood C. 1991. A Public Management For All Seasons?. Public Administration: 69 (spring): 3-19.

15. Osborne David and Gaebler Ted, 1996. Mewirausahakan Birokrasi. terj. Abdul. Rasyid, Jakarta: Pustaka Binaman Pressindo.

16. Duffuaa Salih O, A. Raouf, John Dixon Campbell. 1999. Planning and Control of Maintenance Systems: Modeling and Analysis. Department of Systems Engineering: United States of America.

17. Hanafi, Imam and Nugroho Tri Laksono. 2009. Desentralisasi Fiskal: Kebijakan Perimbangan Keuangan Pemerintah Pusat and Daerah Di Indonesia. Malang: UB Press.

18. Hariyono, Arik.. 2007. Prinsip \& Teknik Manajemen Kekayaan Negara. Jakarta: Departemen Keuangan Republik Indonesia Badan Pendidikan and Pelatihan Keuangan Umum.

19. Fayol, Henry. 1985. Industri and Manajemen Umum. Terj. Winardi, London.

20. Frederickson, H, George. 1984. Administrasi Negara Baru (New Public Administration) Diterjemahkan oleh Al Ghoze, Jakarta: LP3ES.

21. Siagian, S.P. 1995. Manajemen Sumber Daya Manusia. Jakarta: Bumi Aksara.

22. Tjitrosidojo, Soemardjo. 1977. Bunga rampai menuju pemeriksaan pengelolaan (manajemen auditing). Van Hoeve Jakarta: Ichtiar Baru. 